\title{
Systematic and Plant Geography Analysis of Irobo Forest (Ivory Coast)
}

\author{
Ehikpa N'dri Marie Manuela ${ }^{1}$, Kouassi Roland Hervé ${ }^{2}$, Assi Kaudjhis Chimène ${ }^{3}$, Justin Kassi N'dja ${ }^{4 *}$
}

\author{
${ }^{1}$ Doctorante, UFR Biosciences, Université Félix Houphouët-Boigny, 22 BP 582 Abidjan (Côte d'Ivoire) \\ ${ }^{2}$ Maître de Conférences, Ecole Normale Supérieure, Abidjan, 22 BP 582 Abidjan (Côte d'Ivoire) \\ ${ }^{3}$ Maître-Assistant, UFR Biosciences, Université Félix Houphouët-Boigny, 22 BP 582 Abidjan (Côte d'Ivoire) \\ ${ }^{4}$ Professor, UFR Biosciences, Université Félix Houphouët-Boigny, 22 BP 582 Abidjan (Côte d'Ivoire)
}

DOI: $\underline{10.36347 / \mathrm{sajb} .2020 . \mathrm{v} 08 \mathrm{i} 10.006}$

| Received: 08.10.2020 | Accepted: 21.10.2020 | Published: 26.10.2020

*Corresponding author: Justin Kassi N'dja

Abstract

Four hundred and forty-eight (448) species have been recorded in Irobo forest (Ivory Coast) during field investigations, distributed among 301 genera and 92 families. Among those species, 387 (86.38\%), 20 (4.46\%) and $18(4.02 \%)$ are phanerophytes, geophytes and hemicryptophytes, respectively. Most species bear small, fleshy fruits that are dispersed by animals, either by endozoochory $(262$ species $=62.68 \%)$ or by epizoochory $(29$ species $=6.94 \%)$. A significant amount of species $(111=26.56 \%)$ exhibits fruits with appendices facilitating their wind-dispersion. Phytochory analysis shows relevant proportion of endemic Guineo-Congolian species $(265$ species $=59.15 \%)$ compared to widespread species. 32 species (7.14\%) are Guineo-Congolian species that are endemic from West Africa, among which only two are endemics from Ivory Coast. Those proportions indicate that the forest under study is included in rainforest sensu Guillaumet \& Adjanohoun, and match with the endemism Guineo-Congolian zone defined by White. Unfortunately, this forest is gradual degradation due to peasants' infiltrations.

Keywords: Flora, Systematic, Tropical rainforest, Plants geography, Ivory Coast.

Copyright $\left({ }_{0} 2020\right.$ The Author(s): This is an open-access article distributed under the terms of the Creative Commons Attribution 4.0 International License (CC BY-NC 4.0) which permits unrestricted use, distribution, and reproduction in any medium for non-commercial use provided the original author and source are credited.

\section{INTRODUCTION}

The Ivorian flora is well known [1]. It is estimated at 3,660 species [1]. Sixty-two (62) species reported in this flora have, to date, only been observed outside the limits of Ivory Coast [2], which makes it one of the "biodiversity hotspots" on a planetary scale. This author's work has been carried out mainly in the Taï National Park, the Banco forest and the Yapo-Abbé forest massif. Other small forests such as Irobo have not been well sampled by this author. The classified forest has been subject to peasant infiltration. The creation of fields of cocoa, coffee and oil palm since 1970, despite the classification of the forest, has created a mosaic of secondary vegetation included in a matrix of "primary" forest. Recently, thanks to the military-political crisis that shook the country in 2010 , the reserved forest of Irobo has been infiltrated by many peasants seeking forest land to grow crops. The administration has proceeded to an enrichment in species including: Khaya ivorensis A. Chev, Tieghemella heckelii Pierre ex A. Chev. Entandrophragma utile Sprague, for the quality of their timber. The classified forest of Irobo thus remains little known on a scientific level. Nevertheless, like all protected areas, it is of ecological, systematic, ethnobotanical and tourist interest. Human pressure on the forest is strong.
With the aim of a better floristic knowledge, guarantor of a good management of natural resources [3, 4] and to bring our contribution to the realization of the Ivorian flora we propose to make a floristic interpretation of the botanical inventories we have made, on the basis of systematic (at the species level), biological, diaspora dissemination and phytogeographic spectra. The objective of this study is to contribute significantly to a better knowledge of the flora of the reserved forest of Irobo and, beyond that, to provide details on the distribution of species on the scale of the Ivory Coast. More specifically, we will try to answer the following questions: what is the local flora? And what is the phytogeographic affinity of the species of this classified forest?

\section{MATERIAL AND METHOD Study Area and Method}

The study was carried out in the reserved forest of Irobo. This forest, with a surface area of 41, 250 ha, is located in the South of Ivory Coast $\left(3^{\circ} 13^{\prime}\right.$ and $3^{\circ} 24^{\prime}$ West longitude and $5^{\circ} 59^{\prime}$ and $5^{\circ} 41^{\prime}$ North latitude). It is an evergreen dense humid forest, belonging to the ombrophilous sector [5]. Apart from soils on alluvial deposits, two major families of soils can be distinguished 
in the study area. These are soils derived from schists whose original material is clayey-sandy to fine sand with a greater or lesser quantity of gravel and quartz pebbles, and soils derived from granitic rock formed on an original clayey-sandy to coarse sand material [6]. Like the majority of the country's forests, it has been subject to very high anthropogenic pressure, with deforestation followed by the conversion of clearings to intensive coffee and cocoa cultivation since the 1970s. Today, most of the formerly cultivated land is fallow and spontaneously recolonized by forest vegetation. The reserved forest of Irobo is made up of a set of islands of secondary forests of varying ages (depending on the age of the crops), included in a matrix of forest considered old.

\section{DATA COLLECTION}

The sampling plan was designed to inventory the evergreen forest (or old forest, $n=12$ surveys), the post-cultivation fallows, classified into four (4) plant groupings according to age. These are: 1-10 year old fallow (category $1, \mathrm{n}=18$ records), 11-20 year old fallow (category 2, $\mathrm{n}=8$ records), 21-30 year old fallow (category $3, n=6$ records) and fallow 30 years old and older (category $4, n=6$ records). These three types of vegetation formations were considered to represent a gradient of increasing human pressure on vegetation. Survey size was $100 * 20 \mathrm{~m}=2000 \mathrm{~m}^{2}$. The vegetation survey consisted of an exhaustive list of all vascular species present in the 50 plots. Complementary itinerant inventories were carried out in all parts of the forest. These inventories made it possible to complete the floristic list. All the species were identified thanks to the work of $[1,7]$. The nomenclature adopted is that of [8].

\section{DATA ANALYSIS}

We have established a floristic catalog including all the species present in our 45 vegetation surveys, to which we have added the additional species identified during the itinerant surveys. The types of phytogeographic distribution were established according to the major chorological subdivisions for Africa proposed by [9]. The biological types that are used take into account the modifications and adjustments proposed for tropical environments [4]. Concerning the modes of dissemination of diaspores in tropical areas (seeds, fruits or any other plant part used for the dissemination of the species), we have followed the classification used by [10].

\section{RESULTS \\ Floristic Composition}

The floristic balance of the reserved forest of Irobo shows 448 species distributed in 92 families and 301 genera. The Angiosperms Dicotyledons are the best represented $(88,84 \%)$. Monocotyledons represent $10.27 \%$ while Pteridophytes are poorly represented $(0.89 \%)$. The Fabaceae family with 56 species or a rate of $12.50 \%$ is the best represented. It is followed by the families Malvaceae (26 species; 5.80\%), Apocynaceae (23 species; 5.13\%), Euphorbiaceae and Moraceae (with 22 species; $4.91 \%$ each), Rubiaceae (20 species; 4.46\%), Maliaceae (15 species; 3.35\%), and Annonaceae (14 species; $3.13 \%$ ). Table I, gives for each family the number of genera and species followed by their respective percentages in the total flora. This table makes it possible to achieve the first objective of this study, namely the inventory of the flora of the Irobo massif. Among the 301 genera that make up the reserved forest of Irobo, the Ficus genus is the most abundant with 12 species. It is followed by the genera Cola and Landolphia with seven species each.

\section{Conservation value of the biodiversity of the reserved forest of Irobo}

The botanical inventory provided information on the diversity and particularity of the Irobo massif. Among the species recorded in this forest, 32 (7.14\% of the total number) are West African endemic (GCW) and 2 of them are Ivorian endemic (GCi). These are Baphia bancoensis Aubrév. and Chrysophyllum taiense Aubrév $\&$ Pellegr. Comparison of the general list of species of the massif with that of the IUCN and that of Aké-Assi enabled us to identify 33 species $(7.37 \%)$ appearing on the IUCN Red List and 9 species $(2.01 \%)$ appearing on the Aké-Assi list as species that have become rare or endangered (Cola heterophylla (P. Beauv.) Schott and Endl., Diospyros vignei White, Erythrina vogelii Hook. f.). Of the 32 species found on the IUCN Red List, 17 are Vulnerable (VU), 9 are classified as Least Concern (LC), 1 is Endangered (EN), 1 is Data Deficient (DD) and 5 are Low Risk (L.R). 
Ehikpa N'dri Marie Manuela et al., Sch Acad J Biosci, Oct, 2020; 8(10): 338-343

Table-1: Main families of the flora of the reserved forest of Irobo

\begin{tabular}{|c|c|c|c|c|c|}
\hline \multirow[t]{2}{*}{$\mathrm{N}^{\circ}$} & \multirow[t]{2}{*}{ Familles } & \multicolumn{2}{|l|}{ Genres } & \multicolumn{2}{|l|}{ Espèces } \\
\hline & & Effectifs & Proportions (\%) & Effectifs & Proportions (\%) \\
\hline 1 & Fabaceae & 38 & 12.62 & 56 & 12.50 \\
\hline 2 & Malvaceae & 16 & 5.32 & 26 & 5.80 \\
\hline 3 & Apocynaceae & 15 & 4.98 & 23 & 5.13 \\
\hline 4 & Euphorbiaceae & 17 & 5.65 & 22 & 4.91 \\
\hline 5 & Moraceae & 8 & 2.66 & 22 & 4.91 \\
\hline 6 & Rubiaceae & 15 & 4.98 & 20 & 4.46 \\
\hline 7 & Meliaceae & 9 & 2.99 & 15 & 3.35 \\
\hline 8 & Annonaceae & 9 & 2.99 & 14 & 3.13 \\
\hline 9 & Poaceae & 10 & 3.32 & 12 & 2.68 \\
\hline 10 & Sapotaceae & 7 & 2.33 & 11 & 2.46 \\
\hline 11 & Sapindaceae & 5 & 1.66 & 9 & 2.01 \\
\hline 12 & Combretaceae & 3 & 1.00 & 8 & 1.79 \\
\hline 13 & Convolvulaceae & 3 & 1.00 & 8 & 1.79 \\
\hline 14 & Ebenaceae & 1 & 0.33 & 8 & 1.79 \\
\hline 15 & Arecaceae & 6 & 1.99 & 7 & 1.56 \\
\hline 16 & Celastraceae & 4 & 1.33 & 7 & 1.56 \\
\hline 17 & Anacardiaceae & 5 & 1.66 & 6 & 1.34 \\
\hline 18 & Araceae & 5 & 1.66 & 6 & 1.34 \\
\hline 19 & Lamiaceae & 3 & 1.00 & 6 & 1.34 \\
\hline 20 & Clusiaceae & 4 & 1.33 & 5 & 1.12 \\
\hline 21 & Marantaceae & 4 & 1.33 & 5 & 1.12 \\
\hline 22 & Rutaceae & 4 & 1.33 & 5 & 1.12 \\
\hline 23 & Olacaceae & 3 & 1.00 & 5 & 1.12 \\
\hline 24 & Solanacea & 2 & 0.66 & 5 & 1.12 \\
\hline 25 & Dioscoreaceae & 1 & 0.33 & 5 & 1.12 \\
\hline 26 & Violaceae & 1 & 0.33 & 5 & 1.12 \\
\hline 27 & Menispermaceae & 4 & 1.33 & 4 & 0.89 \\
\hline 28 & Commelinaceae & 2 & 0.66 & 4 & 0.89 \\
\hline 29 & Passifloraceae & 2 & 0.66 & 4 & 0.89 \\
\hline 30 & Phyllanthaceae & 2 & 0.66 & 4 & 0.89 \\
\hline 31 & Vitaceae & 2 & 0.66 & 4 & 0.89 \\
\hline 32 & Asparagaceae & 1 & 0.33 & 4 & 0.89 \\
\hline 33 & Loganiaceae & 1 & 0.33 & 4 & 0.89 \\
\hline 34 & Asteraceae & 3 & 1.00 & 3 & 0.67 \\
\hline 35 & Bignoniaceae & 3 & 1.00 & 3 & 0.67 \\
\hline 36 & Brassicaceae & 3 & 1.00 & 3 & 0.67 \\
\hline 37 & Connaraceae & 3 & 1.00 & 3 & 0.67 \\
\hline 38 & Irvingiaceae & 3 & 1.00 & 3 & 0.67 \\
\hline 39 & Lauraceae & 3 & 1.00 & 3 & 0.67 \\
\hline 40 & Lecythidaceae & 3 & 1.00 & 3 & 0.67 \\
\hline 41 & Verbeneceae & 3 & 1.00 & 3 & 0.67 \\
\hline 42 & Cannabaceae & 2 & 0.66 & 3 & 0.67 \\
\hline 43 & Cyperaceae & 2 & 0.66 & 3 & 0.67 \\
\hline 44 & Melastomataceae & 2 & 0.66 & 3 & 0.67 \\
\hline 45 & Ochnaceae & 2 & 0.66 & 3 & 0.67 \\
\hline 46 & Others (47) & 57 & 18.94 & 63 & 14.06 \\
\hline
\end{tabular}

\section{Biological Types and Modes of Diaspora Dispersion Biological Types}

The biological spectrum of the species inventoried (Fig-1) shows a clear dominance of phanerophytes with 387 species or $86.38 \%$. Then come the geophytes with 20 species or $4.46 \%$. The hemicryptophytes and the chamephytes, present respectively proportions of $4.02 \%$ (18 species) and $2.45 \%$ (11 species). The therophytes and the epiphytes present respectively proportions of $1.34 \%$ (6 species) and $0.67 \%$ ( 3 species). Microphanerophytes with 181 species $(40.40 \%$ of the total number) are dominant in phanerophytes, followed by mesophanerophytes (100 species, 22.32\%), nanophanerophytes (66 species, 
$14.73 \%$ ) and megaphanerophytes with 40 species, $8.83 \%$ of the total number. It should be noted that 95 of these phanerophytes are lianas. Analysis of the biological types will give an idea of the structural characteristics of our study area.

\section{Modes of Diaspora Dispersion}

These different taxa inventoried in the classified forest can be divided into five modes of diaspora dissemination (Fig-2). These are: endozoochory, anemochory, epizoochory, barochory and hydrochory. The endozoochory with 262 species or $62.68 \%$ of the total number is the most representative mode of dissemination of species in the forest (Fig-2). It is followed by anemochory with 111 species $(26.56 \%)$, epizoochory (29 species; 6.94\%) and barochore species (15 species; 3.59\%). Hydrochoreous species (1 species; $0.24 \%$ ) are less represented in the site.

\section{Phytochories}

The taxa recorded in the classified forest studied are distributed according to their chorological affinities (Figure-3). The Guineo-Congolese (GC) taxa, representing $59.15 \%$ (265 species) are the most predominant (Fig-3). The other phytochories, with more than 10 species are, in decreasing order of taxa, Afrotropical (AT) taxa with $9.33 \%$ (42 species), Guineo Congolese \& Sudano-Zambézian (GC-SZ) and introduced taxa (I) with $8.04 \%$ (36 species) each, and cosmopolitan taxa from the Pantropical (Pan) regions with 7, 59\% (34 species), taxa of the African Pluriregional (PA) with $4.02 \%$ (18 species), taxa of the Palaeotropical (Pal) regions with $1.12 \%$ (5 species), taxa of the Sudano-Zambian (SZ) regions with $0.22 \%$ (1 species), taxa of the Afro-Malagasy (AM) regions with $0.45 \%$ ( 2 species) and those of the African-American (Aam) regions with $2.01 \%$ (9 species).

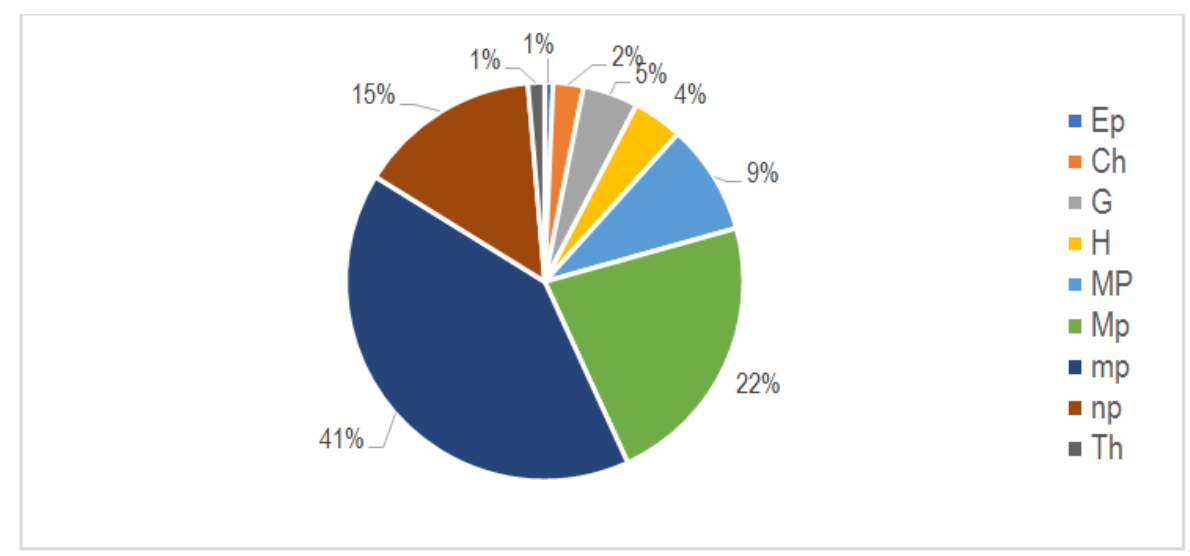

Fig-1: Spectrum of the biological types of the flora of the reserved forest

Legend: $\quad \mathrm{mp}$ : Microphanerophytes, Mp: Hemicryptophytes, Ch: Chamephytes, Ep: Epiphytes, Mesophanerophytes, np: Nanophanerophytes, MPh: Th: Therophytes

Megaphonerophytes, G: Géophytes, H:

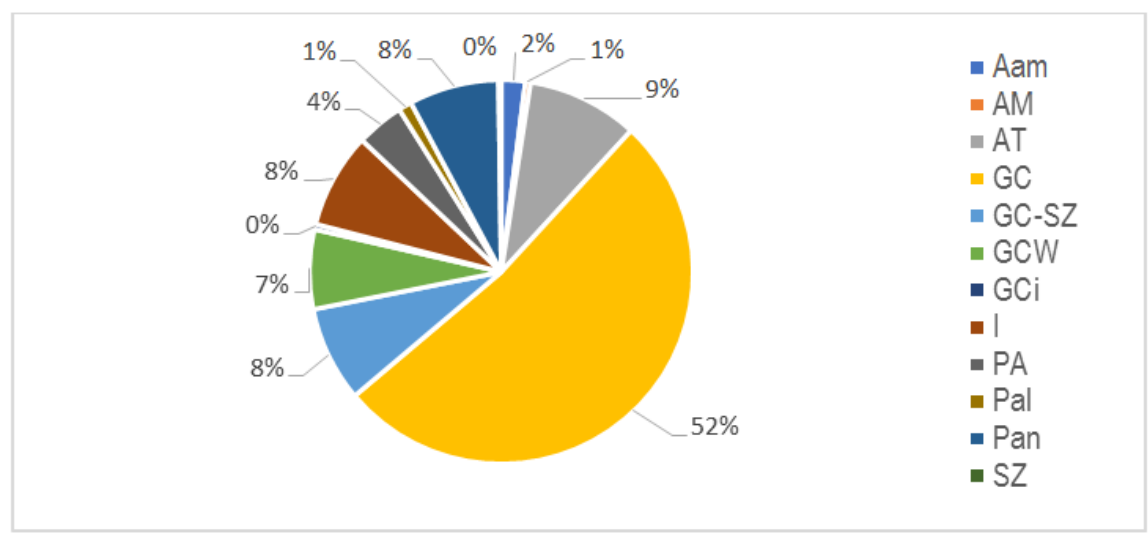

Fig-2: Chorological spectrum of the flora of the reserved forest

Legend : AT : Afrotropicales ; Pal : Paleotropicales ; Pan : Pantropicales ; Aam : African-American ; PA : African Pluriregional, GC : Guineo Congolese; GCW : endemic species of West Africa, GCi : endemic species of Côte d'Ivoire, SZ : Sudano-Zambézian ; GC-SZ : transition GC \& SZ, I : Introduced, Aam, AM: Afro-Malagasy. 


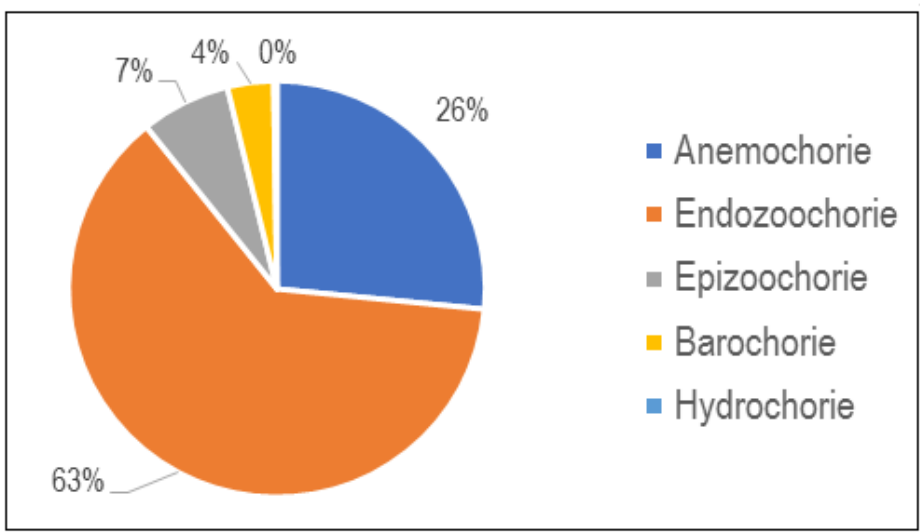

Fig-3: Spectrum of spread of diasporas of forest species

\section{DISCUSSION}

The reserved forest of Irobo did not have any reference flora. Botanical inventories have enabled 448 species to be counted over a surface area of 41,250 hectares. The reserved forest of Irobo owes its floristic richness to the association of natural and anthropised biotopes found there. This is unfortunately the case of several reserved forests in Ivory Coast: the reserved forest of Sanaïmbo [4], the reserved forests of Duekoué and Scio [14], the reserved forest of Bamo [4] and the reserved forest of Agbo 1 [12], to name but a few. According to [11], it is sufficient for natural and anthropised biotopes to coexist for their respective floristic processions to interconnect and increase local floristic richness. The families Fabaceae, Malvaceae, Apocynaceae, Euphorbiaceae, Moraceae, Rubiaceae, Meliaceae and Annonaceae that occupy a prominent place in the reserved forest of Irobo are also reported by [1] as the most numerous in Ivory Coast. Studies conducted in several regions of Ivory Coast, [12] and [4] also highlight the preponderance of these families. The compilation of inventories of Angiosperms collected in Ivory Coast and conserved at the Herbarium of the University Félix Houphouët-Boigny [1] makes it possible to highlight the main families of Ivory Coast. The forest appears as a mosaic of stands at different stages of maturity. Although it is subject to numerous anthropic disturbances, the forest of Irobo still remains a diversified forest in the same way as other Ivorian forests.

The biological spectrum of the Irobo reserved forest is characterized by the dominance of phanerophytes $(86.38 \%$ ). The other biological forms are poorly represented in the forest. Numerous analyses of biological spectra of dense humid forest lead to the same conclusions, i.e. the same proportions [4].

The importance of zoochory is reported in most of the work on the forests of Ivory Coast [11], as is the dominance of zoochory species in the Congo Basin, with proportions very generally above $50 \%$ [10]. In the classified forest of Irobo, the modes of dissemination of fruits and seeds are, on the whole, favoured by animals (endozoochory: 62.68\%, epizoochores: 6.94\%). This dissemination mainly involves birds and some frugivorous vertebrates, notably antelopes, monkeys, rats and squirrels. In the Dja forest in Cameroon, [10] showed that a significant number of animals depended on fleshy fruit species for food. Conversely, the regeneration and maintenance of these species can only be ensured if the diaspores have been dispersed by the animals. The existence of a good balance between these two factors therefore constitutes a guarantee for the sustainability of the forest. [13] showed that in Panama, some Capuchin monkeys (Cebus capucinus) carried seeds 200 or even $1000 \mathrm{~m}$ from the parent tree. And seedlings from seeds transported by endozoochories are more competitive, since they avoid competition with the parent plant. These considerations suggest that the poaching observed in the Irobo classified forest could have negative effects on the dynamics of the forest.

The widespread families (Fabaceae, Malvaceae, Apocynaceae, Euphorbiaceae, Moraceae, Rubiaceae, Meliaceae and Annonaceae) of the Irobo massif are largely made up of Guineo-Congolese taxa $(59.15 \%)$. For [10], the high proportion of widely distributed species reflects the openness of the flora to external influences. These species are most often ruderal species or species from disturbed environments. A high proportion of widely distributed species can indeed be an index of degradation because the flora loses its specificity [11]. The importance of the widespread species, the Guineo-Congolese \& Sudano-Zambézian (GC-SZ) species and the introduced taxa (I) with $8.04 \%$ (36 species) is justified insofar as the reserved forest of Irobo is today a mosaic of vegetation due to peasant infiltration. The reserved forest of Irobo presents a great floristic variability linked in part to the variability of its habitats. For [4], phytogeography is therefore a main tool for the management and conservation of species. It allows assumptions to be made on the age, geographical origin, rate of evolution and migration routes of taxa in the domain. 
According to [1, 2], the Ivorian flora has 62 endemic species of its own (Ivorian). Among these species, only two species Baphia bancoensis Aubrév. and Chrysophyllum taiense Aubrév. \& Pellegr. are present in the flora of Irobo. 30 other West African endemic species have been inventoried in the Irobo forest, compared with 408 species in the Ivorian flora [1]. None of the genera and families of the flora of Irobo is endemic to the Ivorian flora. Nevertheless, the flora is characterized by the presence of numerous taxa of conservation interest, making this forest an important element in the conservation of biodiversity in Ivory Coast. Taking into account the historical aspect, i.e. the human pressures on this reserved forest, we can say that the flora has not completely lost its specificity, since the proportion of widely distributed species is only $31.44 \%$, with $8.04 \%$ of link species. A high proportion of widely distributed species may be an indication of degradation. On the contrary, these different proportions confirm the fact that the study area belongs to the zone of evergreen dense forest defined by [5], which corresponds to the center of Guinean-Congolese floristic endemism whose original vegetation is made up of evergreen dense humid forest as defined by [9]. The flora would seem to reflect rather the overall floristic history, including plant endemism.

\section{CONCLUSION}

The list of species of the reserved forest of Irobo, totals 448 species, divided into 301 genera and 92 families. The aim of such a study is to have the floristic composition of a defined area at a given time. It constitutes a very good basic tool for further research. It emerges, from this floristic study, that the flora of the Irobo classified forest is much diversified at the level of species, genera and families. Phanerophytes dominate, which is classic in a forest. The main modes of dispersion of diasporas are zoochory and anemochory. Animals are said to play a rather notable role in the dissemination and indirectly in the good functioning of this forest. The chorological structure of the classified forest as it appears in our results is very comparable to that of the evergreen dense humid forest formations. Unfortunately, the forest is progressively deteriorating due to peasant infiltration. It is therefore urgent to involve the local population more in forest management.

\section{REFERENCES}

1. Aké-Assi L. Flore de la Côte d'Ivoire: Etude descriptive et biogéographique avec quelques notes ethnobotaniques. (Doctoral dissertation, Abidjan). 1984, 1206.
2. Aké-Assi L. Espèces rares et en voie d'extinction de la flore de la Côte d'Ivoire. Monographie, Systématique et Botanique. 1988; 25:461-463.

3. Yangakola, JM, De Foucault B, Yongo OD, Lejoly J. Analyse phytogéographique comparative des savanes et des forêts de Ngotto (République Centrafricaine). Acta Botanica Gallica. 2004; 151:124-227.

4. Kassi NJ, Tiébre MS, Aké-Assi E. Les Pratiques culturales influencent-elles la diversité des jachères en système de forêt semi-décidue ? European Journal of Scientific Research. 2012; 68(4):523-533.

5. Guillaumet JL, Adjanohoun E. La végétation de la Côte d'Ivoire. In : Avenard JM, Eldin E, Girard G, Sircoulon J, Touchebeuf P, Guillaumet JL, Adjanohoun E, Perraud A. Le milieu naturel de la Côte d'Ivoire. Mémoires ORSTOM. 1971; 50:157-263.

6. Perraud A. Les sols. In : Avenard JM, Eldin E, Girard G, Sircoulon J, Touchebeuf P, Guillaumet JL, Adjanohoun E, Perraud A. Le milieu naturel de la Côte d'Ivoire. Mémoires de l'ORSTOM 50, paris (France). 1971; 269-389.

7. Lebrun JP, Stork AL. Enumération des plantes à Fleurs d'Afrique Tropicale. Conservatoire et Jardin Botaniques de la Ville de Genève, Genève (Suisse). 1991-1997; 1(249).

8. APG IV. An update of the Angiosperm Phylogeny Group classification for the ordersand families of flowering plants. Botanical Journal of the Linnean Society. 2016; 181:1-20.

9. White F. La végétation de l'Afrique. Recherche sur les ressources naturelles. ORSTOM-UNESCO, Paris (France). 1986; XX, 384.

10. Sonké B. Etudes floristiques et structurales des forêts de la réserve de faune du Dja, Cameroun. (Doctoral dissertation, Bruxelles, Belgique). 1998; 267.

11. Kouamé NF. Structure de la végétation, flore et régénération des forêts classées de Duekoue et de Scio dans la zone de forêt dense humide de l'Ouest ivoirien. (Doctoral dissertation, Abidjan, Côte d'Ivoire). 2016; 282.

12. N'Guessan AE, Kassi NJ. Diversity And Structure of Agbo Forest (Côte d'Ivoire). Scholars Academic Journal of Biosciences (SAJB). 2018; 6(3):252-258.

13. Rowell TE, Mitchell BJ. Comparaison of seed dispersal of guenons in Kenya and Capuchins in Panama. Journal of Tropical Ecology. 1991; 7: 269-274. 